\title{
Chemical Composition of Quasi-ultrafine Particles and their Sources in Elderly Residences of São Paulo Megacity
}

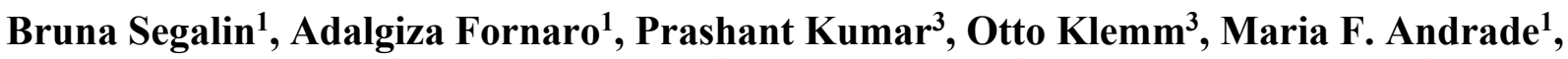 \\ Beatriz Maria Trezza $^{4}$, Alexandre Busse ${ }^{4}$, Wilson J. Filho ${ }^{4}$, Fabio L.T. Gonçalves ${ }^{1^{*}}$
}

${ }^{1}$ Departamento de Ciências Atmosféricas, Instituto de Astronomia, Geofísica e Ciências Atmosféricas, Universidade de São Paulo, 05508-090, São Paulo, SP, Brasil

${ }^{2}$ Global Centre for Clean Air Research (GCARE), Department of Civil and Environmental Engineering, Faculty of Engineering and Physical Sciences, University of Surrey, Guildford GU2 7XH, UK

${ }^{3}$ University of Münster, Climatology Research Group, 48149 Münster, Germany

${ }^{4}$ Divisão de Geriatria, Departamento de Medicina Interna, Faculdade de Medicina, Universidade de São Paulo, $01246-$ 903, São Paulo, SP, Brasil

\begin{abstract}
Atmospheric quasi-ultrafine particles (qUFP; $\mathrm{PM}_{<0.25}$ ) can cause harmful effects to human health, mainly to elderly people. Although not always considered, these effects can be mostly due to its chemical composition. The scope of this work is (i) to quantify the abundance of ions and trace elements in qUFP in elderly residences, (ii) to identify the sources of these qUFP and (iii) to estimate the respiratory deposition doses (RDD) of qUFP and black carbon (rBC), which is an important component of qUFP, to various parts of the respiratory tract. In order to evaluate the qUFP chemical composition in elderly residences in the Metropolitan Area of São Paulo (MASP), we collected qUFP by using a Personal Cascade Impactor Sampler (PCIS). We analysed ions by chromatography and trace elements by Energy Dispersive X-Ray Fluorescence. We identified the sources of qUFP by applying Positive Matrix Factorization. We calculated the RDD through an equation, which use the tidal volume of lung, the typical breath frequency, the deposition fraction and the mass concentration of different size fractions of a PM. We collected 60 samples from 59 residences between May 2014 and July 2015. The major of ions concentrations in qUFP were found to be $\mathrm{SO}_{4}{ }^{2-}$ and $\mathrm{NH}_{4}{ }^{+}$, and the major trace elements were $\mathrm{Si}$ and Fe. Some residences have a high concentration of the toxic heavy metals $\mathrm{Cu}, \mathrm{Ni}, \mathrm{Pb}$ and $\mathrm{Cr}$. We found six dominant sources of the indoor qUFP: vehicular emission (57\%), secondary inorganic aerosol (21\%), soil and construction (7\%), wall painting (7\%), cooking (5\%) and industry (3\%). The maximum RDD of qUFP and $\mathrm{rBC}$ are in the tracheobronchial part. Our results show that vehicular emissions dominate the indoor qUFP concentrations and uptake in elderly residences in the MASP.
\end{abstract}

Keywords: Indoor air quality; Chemical composition; quasi-ultrafine particulates; Elderly residence; Indoor sources; Respiratory deposition doses

\section{INTRODUCTION}

Atmospheric aerosol particles in the urban environment are characterized by different sizes, shapes, and chemical composition (Heal et al., 2012; Kumar et al., 2014). Particles smaller than $0.1 \mu \mathrm{m}$ in diameter, also referred to as ultrafine particles (UFP), typically occur in large number concentrations while their contribution to the mass concentration is marginal (Kumar et al., 2010; Rivas et al., 2017). On the other hand, coarse particles are low in number but contribute largely to the mass concentration (PM). The UFP contribute to about

\footnotetext{
${ }^{*}$ Corresponding author.

E-mail address: fabio.goncalves@iag.usp.br
}

$80 \%$ of the total number concentrations of the atmospheric particles and the ones with diameter up to $0.3 \mu \mathrm{m}$ contribute to over 99\% (Kumar et al., 2009, 2010). It is reported that the smaller the particles, the larger their toxic potential. For example, particles with diameters less than $0.25 \mu \mathrm{m}$ have higher redox activity (induce oxidative stress in human cells) than coarse and accumulation modes of particles ( $\mathrm{Hu}$ et al., 2008). The UFP can also translocate for the bloodstream and achieve other organs such as brain and heart (Elder et al., 2006; Heal et al., 2012). From this perspective, it is very important to study particles of that size range. In this work, we aim to focus on particles with diameters up to $0.25 \mu \mathrm{m}$, which we refer to as quasi-ultrafine particles (qUFP), hereafter. This concept has also been utilized in earlier studies (Arhami et al., 2009; Hu et al., 2008; Saffari et al., 2013; Viana et al., 2014). The qUFP is an operational definition. In contrast to 
a significant number of studies on the chemical composition of ambient larger particles, there is hardly any study on the chemical composition of qUFP, specifically if it comes to indoor air pollution (Viana et al., 2014). This is comprehensible in light that the high mass concentrations of particles are expected to be in the coarse and accumulation ranges.

In this work, we sampled qUFP in elderly residences in order to analyze trace elements and ions concentrations. We focused on the elderly population because it is fastest growing in worldwide (United Nations, 2015) and they are a risk group for particles air pollution (Peled, 2011). The expected trend is the increase from 841 million of elderly in 2013 to more than 2 billion in 2050 when they will surpass the number of children (Chatterji et al., 2015). As the elderly population increases, we will have an epidemic of chronic diseases, mainly dementias, cerebrovascular accident, chronic obstructive pulmonary disease, diabetes, heart failure and coronary insufficiency (Mathers et al., 2015). In fact, the elderly are more likely to have multi-morbidities, either by the progressive decrease of the functional reserve related to the senescence process or by the greater exposure to the risk factors. Therefore, they are a risk group for particles of air pollution (Peled, 2011). Aerosol particles can cause many problems in elderly people such as a change in heartbeat frequency (Holguín et al., 2003), aggravate chronic obstructive pulmonary disease (Osman et al., 2007) and cognitive deficit (Weuve et al., 2012). We also focus on the indoor environment because elderly people spend about $80 \%$ of their time indoors (Segalin et al., 2017), which can be most relevant for their health. In the best of our knowledge, this is the first study in elderly residences in a Latin American megacity, such as São Paulo, to study the chemical characteristics of the qUFP.

While the sheer number concentration of qUFP is a good indicator of the potential health effects, the chemical composition of these particles is equally or even more important to be considered in health impact assessment (Saffari et al. 2013). For example, airborne urban particles compositions, including those of qUFP, are characterized by several metals such as aluminium (Al), arsenic (As), cadmium $(\mathrm{Cd})$, lead $(\mathrm{Pb})$, manganese $(\mathrm{Mn})$, and mercury (Hg), which affect the neurological system (Pohl et al., 2011). Likewise, metals such as $\mathrm{Al}, \mathrm{Pb}, \mathrm{Hg}$, zinc $(\mathrm{Zn})$, copper $(\mathrm{Cu})$ and iron ( $\mathrm{Fe})$ have been clearly associated with Alzheimer's disease, which affects elderly people (Lovell et al., 1998; Polizzi et al., 2002; Zatta, 2003; Zatta and Frank, 2007). Black carbon (BC) can affect negatively the respiratory system and cognition of elderly people (Jansen et al., 2005; Power et al., 2013). Exposure to silica (Si) has been associated with kidney disease, lung cancer, rheumatoid arthritis, tuberculosis and pneumoconiosis (Steenland et al., 2001; Attfield and Costello, 2004). Moreover, nickel (Ni) and vanadium $(\mathrm{V})$ together have negative effects on cardiac function and influence in the short-term mortality (Campen et al., 2001). Similarly, BC combined with iron and nickel has been found to affect the cardio regulatory system (Chang et al., 2007). All these metals are components of qUFP, which are the focus of this study. For example, $\mathrm{Hu}$ et al. (2008) reported highest concentrations of $\mathrm{Na}$ and $\mathrm{S}$ in qUFP collected in Los Angeles - Long Beach Harbor. Further,
Viana et al. (2014) studied qUFP inside schools in urban environments and found that most chromium $(\mathrm{Cr})$ and $\mathrm{Ni}$ (metals with high redox properties) are present in qUFP rather than in larger particles.

The main indoor source of airborne particles is resuspension from vacuum cleaning, soap/cleaning sprays, smoking, incense burning and cooking, mainly frying activities ( $\mathrm{Vu}$ et al., 2017). Vacuum sweeping, biological and mineral sources produce predominantly coarse particles (Kamnes et al., 1991). Indoor combustion sources (cooking, wood burning, candle burning, fireplace or kerosene heating) produce mainly particles with diameters below $1 \mu \mathrm{m}$ (Hussein et al., 2006; Kumar et al., 2013). For UFP, cooking was the most important indoor source (Bhangar et al., 2011). Certainly, outdoor air is also a source for indoor PM, which holds especially for qUFP and UFP because they can best penetrate the natural and artificial ventilation systems (Abt et al., 2000). In schools, for example, the indoor qUFP had major trace elements and ions sources from outdoor (Viana et al., 2014; Table 1). In the Metropolitan Area of São Paulo (MASP), many trace elements with health effects such as $\mathrm{BC}, \mathrm{Cu}, \mathrm{Zn}$, $\mathrm{Pb}, \mathrm{Fe}$ and $\mathrm{V}$ were associated with vehicular sources (Andrade et al., 2012; Miranda et al., 2012). The PM fraction from the vehicular traffic combustion processes aggravates ischemic heart disease in the elderly (Lanki et al., 2006).

We intend to quantify how large the contribution of vehicular emissions is to indoor air pollution in elderly residences. We also want to identify the other possible sources for qUFP. Some studies about indoor air pollution identify various sources of UFP doing measurements specifically for each possible source, human activities and with a focus on the number of particles generated (Table 1). Only one study analysed the source of indoor qUFP based on their chemical composition (Viana et al., 2014; summarized in Table 1). In the best of our knowledge, there are no studies of source attribution for outdoor qUFP and UFP in Brazil, and also no information available about the source of airborne particles in residences in Brazil. There are hardly any studies focusing on elderly residents. Therefore, this is the first study in Brazil with the objectives (i) to quantify ions and trace elements present in qUFP mass concentration inside elderly residences, (ii) to identify the sources of the qUFP indoor elderly residences and (iii) to estimate the respiratory deposition doses (RDD) of the qUFP and its proportion of black carbon $(\mathrm{rBC})$ in different parts of respiratory tract.

\section{METHODOLOGY}

\section{Site Description and Study Design}

There are more than 21 million inhabitants in MASP out of which 12 million reside in São Paulo City (IBGE, 2016; Kumar et al., 2016; Andrade et al., 2017). The study of the elderly in this region is important because over $12 \%$ of its population is 60 or older. It is worth highlighting that the elderly population is growing fast, not only in MASP but worldwide (Alessandri and Maeda, 2011; United Nations, 2015; IBGE, 2016). The residences sampled in this study are those with at least one elderly volunteer (aged 60 years or older) that were previously approved for this study. Within 
Table 1. Review of past relevant studies including indoor qUFP and UFP.

\begin{tabular}{|c|c|c|c|}
\hline PM types & Environment types & Key conclusions & References \\
\hline UFP & $\begin{array}{l}\text { One } 32 \mathrm{~m}^{3} \text { full-scale } \\
\text { chamber in Horsholm, } \\
\text { Denmark }\end{array}$ & $\begin{array}{l}\text { From } 11 \text { indoor specific sources tested was the combustion } \\
\text { of pure wax candles that produce more number of UFP. }\end{array}$ & $\begin{array}{l}\text { Afshari et al. } \\
(2005)\end{array}$ \\
\hline UFP & $\begin{array}{l}\text { One suburban residence } \\
\text { in Virginia, USA }\end{array}$ & $\begin{array}{l}\text { - Complex cooking was the majority source of UFP number, } \\
\text { followed by outdoor sources. }\end{array}$ & Wallace (2006) \\
\hline UFP & $\begin{array}{l}\text { One laboratory in New } \\
\text { York, USA }\end{array}$ & $\begin{array}{l}\text { - Out of the seven oil tested, soybean, canola, and safflower } \\
\text { oil had the lowest generation of particles }\end{array}$ & $\begin{array}{l}\text { Torkmahalleh } \\
\text { et al. }(2012)\end{array}$ \\
\hline qUFP & $\begin{array}{l}39 \text { Schools in } \\
\text { Barcelona, Spain }\end{array}$ & $\begin{array}{l}\text { - Indoor source for } \mathrm{Zn}, \mathrm{Cu}, \mathrm{Co}, \mathrm{Cl}^{-} \text {, the outdoor source for } \\
\mathrm{Sb}, \mathrm{Ba}, \mathrm{V}, \mathrm{Ni}, \mathrm{Ca}, \mathrm{Al}_{2} \mathrm{O}_{3}, \mathrm{Ti}, \mathrm{K}, \mathrm{Ni}, \mathrm{SO}_{4}^{-2}, \mathrm{NO}_{3}^{-}, \mathrm{NH}_{4}^{+} \text {. }\end{array}$ & $\begin{array}{l}\text { Viana et al. } \\
\text { (2014) }\end{array}$ \\
\hline UFP & $\begin{array}{l}\text { Two residences in } \\
\text { California, USA }\end{array}$ & $\begin{array}{l}\text { - In electric appliances and cooking pans, the sources of } \\
\text { UFP were detergent residue and organics sorbed from } \\
\text { indoor air. }\end{array}$ & $\begin{array}{l}\text { Wallace et al. } \\
(2015)\end{array}$ \\
\hline UFP & $\begin{array}{l}\text { One laboratory in } \\
\text { Piacenza, Italy }\end{array}$ & $\begin{array}{l}\text { - Burn wood in a manual heaters utensil instead pellet in an } \\
\text { automatic produce more UFP with more toxic chemical } \\
\text { composition }\end{array}$ & $\begin{array}{l}\text { Ozgen et al. } \\
(2017)\end{array}$ \\
\hline
\end{tabular}

the framework of this project, we selected volunteers from the Faculty of Medicine Clinics Hospital at the University of São Paulo. The selection criteria were pre-established by the team of geriatricians who selected healthy elderly people without any previous diseases such as diabetes, cardiorespiratory or cancer diseases. All the elderly participants had accomplished at least 4 years of formal education with no neurological or psychiatric illness (Trezza et al., 2015). All of them were submitted to three different tests which are important for evaluating independent living capacity, i.e., (i) the Mini-Mental State Examination (MMSE; Folstein et al., 1975), (ii) the Geriatric Depression Scale (GDS; Sheikh et al., 1991), and (iii) the Short Physical Performance Battery (SPPB; Guralnik et al., 1994). The MMSE is for evaluating any potential presence of a cognitive deficit of the individual. The GDS assesses possible symptoms of depression, while the SPPB checks the balance deficit. Only the elderly that passed all three tests were considered to be in good conditions and thus qualified to be volunteers for this study. In this way, the location of the residences were randomly arranged. All residences were located in the regions with the highest concentration of elderly people within the MASP. We have 59 residences sampled with 60 valid individual samples and referring to 60 approved volunteers. As described by Segalin et al. (2017), only one residence had two samples, collected on different days. Most of these residences sampled in the MASP are located in São Paulo, just two in the city of Osasco and one in Embu das Artes (Fig. 1). The measurements started in the morning in accordance with the availability of the elderly volunteers. The instrument was operated in the living room of the elderly residences for a period of 24 hours in each residence. The residences, as described for Segalin et al. (2017), are natural ventilated and liquefied petroleum gas from individual bottled and piped natural gas was used as cooking fuel. The elderly spend almost $80 \%$ of the 24 hours sampling period inside their residences (Segalin et al., 2017).

\section{Instrumentation}

The PM data came from Segalin et al. (2017), who operated a Personal Cascade Impactor Sampler (PCIS), which separates the PM into five size ranges, i.e., 10-2.5, 2.5-1.0, $1.0-0.5,0.5-0.25$, and $<0.25 \mu \mathrm{m}$ aerodynamic diameters. The quasi-ultrafine particle fraction (qUFP, aerodynamic diameter $<0.25 \mu \mathrm{m}$ ) is thus represented by the last stage of the impactor. The PCIS was described in detail by Misra et al. (2002) and Sioutas, (2004). The PCIS was combined with a Leland Legacy Sample Pump (SKC Inc., Cat. No. 1003000 ) with $9 \mathrm{~L} \mathrm{~min}^{-1}$ rate flow, in order to provide reliable results during the entire $24 \mathrm{~h}$ sampling periods (Sioutas, 2004). The PCIS was used with a $37 \mathrm{~mm}$ Teflon filter for qUFP to avoid any chemical interference with the PM and in chemical analysis (Misra et al., 2002). Although the PCIS is designed as a personal monitor, Segalin et al. (2017) deployed them in the living rooms of the elderly residences. The acceptance and willingness of most elderly people to carry the PCIS as a personal monitor was not good enough, mainly because the pump made a continuous noise (Segalin et al., 2017).

\section{Data Collection and Analysis}

We have 60 samples from 59 residences collected between May 2014 and July 2015 (Segalin et al., 2017). The days of measurements were randomly selected and coordinated with the elderly availability. Thirty-one measurements were made in 2014 and 29 in 2015, most of them during the respective southern winter periods (May, June and July). All elderly that had been approved to the tests (Section 2.1) participated in the campaign throughout. There were no drop-outs. We did not conduct outdoor sampling during the same sampling period due difficulty to get permission to install the instruments outside the building.

The $\mathrm{rBC}$ mass concentration was quantified by optical reflectance measurements with a refractometer (smoke stain reflectometer model 43D; Diffusion Systems Ltd., London, UK) (Segalin et al., 2016). We analysed trace elements present in qUFP using Energy Dispersive X-Ray Fluorescence technique (EDXRF - EDX 700HS; Shimadzu Corporation, Analytical Instruments Division, Tokyo, Japan). The ions analyzes were carried out by using ionic chromatography and 


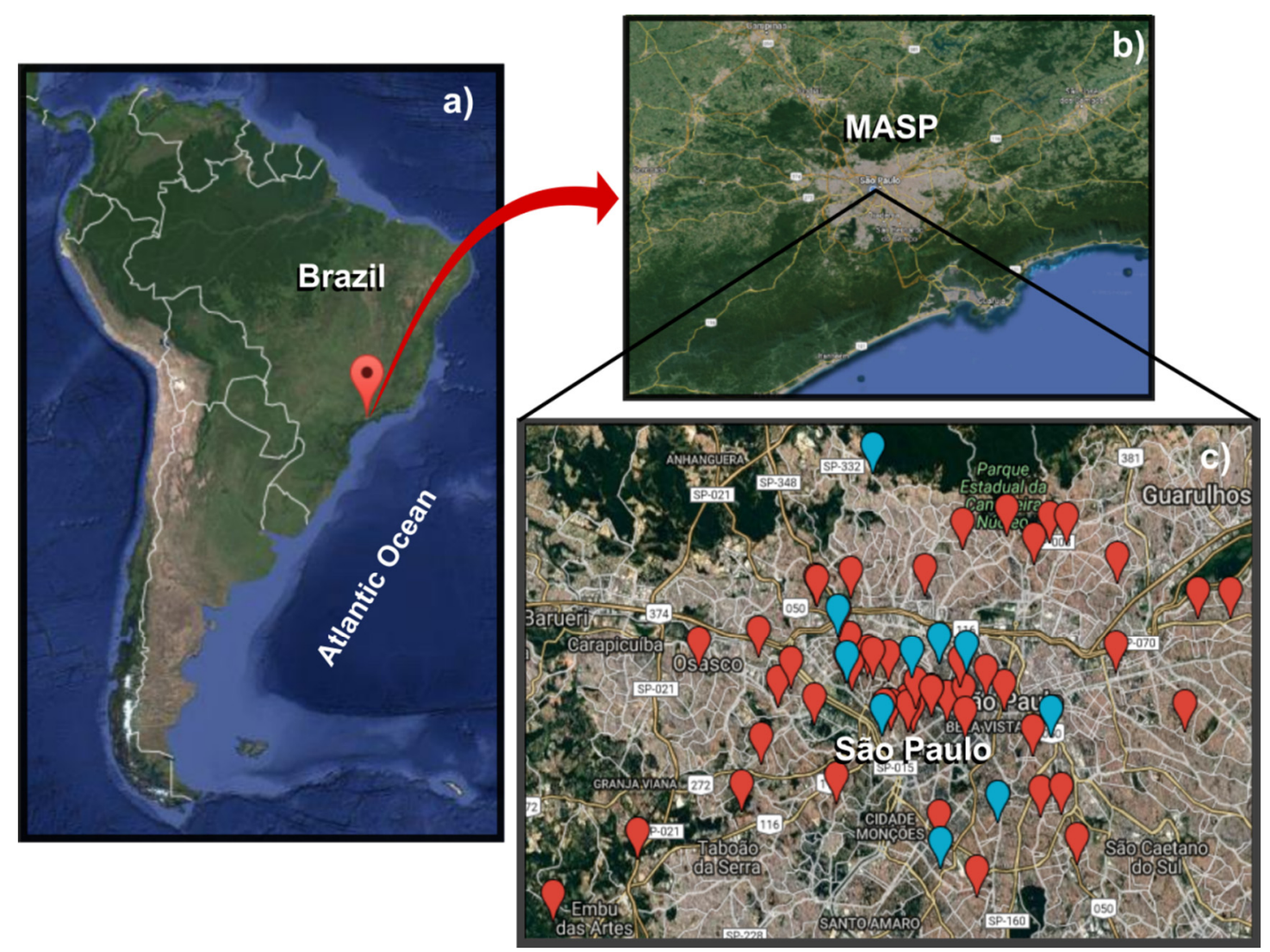

Fig. 1. Localization of (a) São Paulo, Brazil, (b) Metropolitan Area of São Paulo (MASP) and (c) the elderly residences. The different colors in (c) represent the group 1 (red) and 2 (blue) found by clusters analysis in section 3.2. Adapted from Segalin et al. (2017), map by Google Maps.

conductivity detection (Metrohm 850, Herisau, Switzerland). For the aqueous extraction, we placed each Teflon filters in pre-cleaned low-density polyethylene tubes with $10 \mathrm{~mL}$ ultrapure water. These samples were shaken for at least 2.5 hours. Thereafter, the solutions were filtered by Millex polyvinylidene difluoride filters $(0.22 \mu \mathrm{m}$ pore size; Millipore, Bedford, MA, USA), followed by ions analyses with ionic chromatography.

All sample analyses were blank-corrected and the trace elements and ions with $2 / 3$ or more samples below detection limits (DL, see Supplementary information, SI, Tables S1S2; Leal et al., 2004; Arana, 2014) were excluded from this work (Mg, Mn, $\mathrm{Se}, \mathrm{Sr}, \mathrm{Cr}, \mathrm{Cd}, \mathrm{Rb}, \mathrm{V}, \mathrm{Sb}$, As and $\left.\mathrm{C}_{2} \mathrm{O}_{4}{ }^{2-}\right)$. For the remaining samples, the compounds with values below DL were replaced by half of the average of their DL (Polissar et al., 1998; Khan et al., 2016). During further data analysis of mass concentrations, we considered some elements to be present in their oxidized form, for example, aluminum as aluminum oxide $\left(\mathrm{Al}_{2} \mathrm{O}_{3}\right)$ and iron as iron oxide $\left(\mathrm{Fe}_{2} \mathrm{O}_{3}\right)$ (SI, Table S3; Kotz and Purcell, 1987; Hueglin et al., 2005; Beuck et al., 2011).

\section{Cluster Analysis}

In order to group the elderly residence by mass concentration, trace elements and ions, we choose the $p v c l u s t$ package (Suzuki and Shimodaira, 2009) in R programming language for cluster analysis. This algorithm calculates the $p$-value for each cluster in a cluster hierarchy as generated by the hclust function. The pvclust provides approximately unbiased $p$-value (AU; Shimodaira, 2002) to reduce test bias and the bootstrap probability $p$-value (BP) calculated by multiscale bootstrap resampling (Shimodaira, 2004). We chose $A U \geq 95 \%$ as a cut point for the clusters because the clusters are robustly supported by the database with this cut point (Shimodaira, 2004; Suzuki and Shimodaira, 2009). For this analysis, the sample \#27 was removed because it is an outlier with respect to the mass concentration (see also Segalin et al., 2017). We also analysed the meteorological variables for the groups generated by the cluster analyses. We obtain data on temperature, relative humidity, wind speed and precipitation from the meteorological station of Institute of Astronomy, Geophysics and Atmospheric Science (IAG). This station has an average distance of $13.9 \mathrm{~km}$ of the residences (Segalin et al., 2017).

\section{Positive Matrix Factorization (PMF)}

We used the Positive Matrix Factorization (PMF; Paatero and Tapper, 1994) free software by the U.S. Environmental Protection Agency (EPA), version 5.0 (Norris et al., 2014). The PMF is a robust tool to find sources in a particulate matter database (Ogulei et al., 2006a, b; Wallace, 2006; Gietl and Klemm, 2009; Beuck et al., 2011; Amato et al., 2014; Al-Dabbous and Kumar, 2015; Brown et al., 2015; Goel and Kumar, 2015; Khan et al., 2016; Vu et al., 2017). The PMF 
allows us to decompose the data matrix, $\boldsymbol{D}$, into two matrices $\boldsymbol{W}$ and $\boldsymbol{H}$ (Cichocki et al., 2009):

$$
\boldsymbol{D}=\boldsymbol{W H}+\varepsilon
$$

where the matrix $\boldsymbol{W}$ is the matrix with the proportion of each source in each elderly residence, while the matrix $\boldsymbol{H}$ contains the proportion of each ion and trace element in each source, and $\varepsilon$ is the error matrix. In this way, the inputs of PMF are the mass concentration of the variables for each residence and the uncertainties of their mass concentrations (one advantage of the PMF). The uncertainty $\left(\boldsymbol{S}_{i j}\right)$ was calculated with Eq. (2) in accordance with Chueinta et al. (2000), using the estimated measurement error (Eq. (4)) from Ogulei et al. (2006b) and the constant $C=0.04$, that produce the best value proximity between the residual sum of squares $(Q)$ and the theoretical value (Ogulei et al., 2006a):

$\boldsymbol{S}_{i j}=\sigma_{i j}+C \boldsymbol{N}_{i j}$

$\sigma_{i j}=0.01\left(N_{i j}+\underline{N}_{j}\right)$

where $\sigma_{i j}$ is the estimated measurement error, $C$ is a constant, $N_{i j}$ is the mass concentration a $N_{j}$ is the arithmetic mean of the $N j$ values, in the $i$ sample in $j$ variable. An extra modelling uncertainty of $5 \%$ was added in PMF model to cover any methodological error (Khan et al., 2016). We categorize the contributions of elements through value of signal to noise $(\mathrm{S} / \mathrm{N})$ as "bad" $(\mathrm{S} / \mathrm{N}<0.5)$, "weak" $(1.0<\mathrm{S} / \mathrm{N} \leq 0.5)$ and "strong" ( $\mathrm{S} / \mathrm{N} \geq 1.0)$ as suggested by Norris et al. (2014). We further considered as "weak" all those elements with more than $1 / 3$ of data below $\mathrm{DL}\left(\mathrm{Br}, \mathrm{Cr}, \mathrm{Ti}, \mathrm{Ni}\right.$ and $\mathrm{NO}_{3}$; Table 2). For this analysis, sample \#27 was also removed.

We chose the number of the factors following the Brown et al. (2015) methodology. They analyse the $Q_{\text {robust }} / Q_{\text {expected }}$ value, and when the changes in this fraction became small with the increasing of the factors, the optimal solution is the number of the factors before the change became small. The PMF gave us the $Q_{\text {robust }}$ and $Q_{\text {expected }}$ as follow:

$Q_{\text {expected }}=(S \times S S)-((F \times S)+(F \times S S))$

where $S$ are the number of the samples, $S S$ are the strong species and $F$ is the number of the factors. We run the PMF for 3-8 factors and we found the best solution with 6 factors (SI Table S4).

\section{Respiratory Deposition Doses (RDD)}

We calculated the total respiratory deposition doses (RDD) in the respiratory tract of elderly using the Eq. (6) adapted from Hinds (1999) by Azarmi and Kumar (2016) with the same parameter and values used by other studies (Kumar et al., 2017; Segalin et al., 2017; Rivas et al., 2017). The RDD is calculated as:

$$
R D D=(V T \times f) \times D F \times P M_{i}
$$

where $\boldsymbol{V} \boldsymbol{T}$ is a tidal volume ( $\mathrm{m}^{3}$ per breath), $\boldsymbol{f}$ is the typical breath frequency (breath per minute), $\boldsymbol{D F}$ is deposition fraction of qUFP (Hinds, 1999), and $\boldsymbol{P} \boldsymbol{M}_{i}$ is the mass concentration of qUPF. The $\boldsymbol{D F}$ for the head airway, tracheobronchial and alveolar regions were estimated using parameterizations

\begin{tabular}{|c|c|c|c|c|c|c|c|c|}
\hline & $\begin{array}{l}\text { Below } \\
\text { DL* }\end{array}$ & & Average & Stand. Dev. & Max. & $\begin{array}{l}\text { Residence } \\
\text { number of } \\
\text { the max }\end{array}$ & Min. & $\begin{array}{l}\text { Residence } \\
\text { number of } \\
\text { the min }\end{array}$ \\
\hline qUFP $^{a}$ & 0 & $\mu \mathrm{g} \mathrm{m}^{-3}$ & 13.6 & 25.5 & 204 & 27 & 1.72 & 56 \\
\hline $\mathrm{rBC}^{\mathrm{b}}$ & 0 & & 2.78 & 2.32 & 13.1 & 6 & 0.2 & 56 \\
\hline $\mathrm{SO}_{4}^{2-}$ & 0 & & 0.61 & 0.42 & 1.61 & 14 & 0.075 & 2 \\
\hline $\mathrm{NH}_{4}^{+}$ & 5 & & 0.19 & 0.18 & 0.67 & 40 & 0.004 & 2 \\
\hline $\mathrm{K}^{+}$ & 0 & & 0.17 & 0.15 & 0.78 & 60 & 0.011 & 56 \\
\hline $\mathrm{Al}$ & 3 & $\mathrm{ng} \mathrm{m} \mathrm{m}^{-3}$ & 20.8 & 13.8 & 78 & 25 & 2.46 & 36 \\
\hline $\mathrm{Si}$ & 0 & & 42.1 & 33.9 & 167 & 60 & 8.37 & 17 \\
\hline $\mathrm{P}$ & 1 & & 12.7 & 8.9 & 40.2 & 13 & 0.92 & 56 \\
\hline $\mathrm{Ti}$ & 22 & & 3 & 2.1 & 9.16 & 26 & 0.82 & 36 \\
\hline $\mathrm{Cr}$ & 36 & & 1.34 & 1.22 & 6.67 & 60 & 0.57 & 18 \\
\hline $\mathrm{Fe}$ & 0 & & 38.7 & 23.2 & 112 & 5 & 7.14 & 44 \\
\hline $\mathrm{Ni}$ & 23 & & 0.87 & 0.7 & 3.28 & 5 & 0.27 & 36 \\
\hline $\mathrm{Cu}$ & 1 & & 9.46 & 22.5 & 175 & 56 & 0.62 & 44 \\
\hline $\mathrm{Zn}$ & 0 & & 26.7 & 21.4 & 105 & 56 & 3.3 & 44 \\
\hline $\mathrm{Br}$ & 30 & & 2.58 & 2.28 & 10.9 & 5 & 0.82 & 36 \\
\hline $\mathrm{Pb}$ & 18 & & 7.4 & 5.82 & 26.3 & 13 & 1.64 & 36 \\
\hline $\mathrm{Na}^{+}$ & 13 & & 36.3 & 27.6 & 139 & 13 & 7.66 & 36 \\
\hline $\mathrm{Ca}^{2+}$ & 0 & & 15.7 & 12.3 & 62.2 & 9 & 1.29 & 43 \\
\hline $\mathrm{Cl}^{-}$ & 17 & & 9.88 & 16.3 & 82.5 & 60 & 0.55 & 36 \\
\hline $\mathrm{NO}_{3}{ }^{-}$ & 36 & & 42.1 & 73.2 & 426 & 1 & 3.58 & 2 \\
\hline
\end{tabular}

Table 2. Information about mass concentration, trace elements, ions and $\mathrm{rBC}$ of qUFP in elderly residences in MASP.

\footnotetext{
* Number of residences with concentration data below the detection limit (DL); ${ }^{\text {a }}$ Data from Segalin et al. (2017); ${ }^{b}$ Data
} from Segalin et al. (2016). 
according to Hind, 1999 (SI, Table S6 and Eqs. (S1)-(S5)). Since $\boldsymbol{V} \boldsymbol{T}$ and $\boldsymbol{f}$ depend on the physical activity and person gender (Hinds, 1999), we calculated $\boldsymbol{R D D}$ for male and female elderly and we chose light exercise and seated positions as their physical activities, as more appropriate for elderly inside their residences (Segalin et al., 2017).

\section{RESULTS AND DISCUSSION}

\section{Ions and Trace Elements in qUFP}

Fig. 2 shows the concentration of ions and trace elements in qUFP and the correlations among them in elderly residences in the MASP. Both ions and trace elements show high variability and non-normal distributions (Fig. 2(a)), as confirmed by the Shapiro-Wilk normality test. The ions and trace elements are positively asymmetrical, except for $\mathrm{Na}^{+}$ (negatively asymmetrical) and they present high values, except for sulphate $\left(\mathrm{SO}_{4}{ }^{2-}\right)$. The ions $\mathrm{SO}_{4}{ }^{2-}$ and $\mathrm{NH}_{4}{ }^{+}$ correlate highly with each other $(r=0.9$, Fig. 2(b)). They do not correlate significantly with most other ions and trace elements (Fig. 2(b)). The total mass concentration has no significant correlations with trace elements, just a weak negative correlation with $\mathrm{Cu}(\mathrm{r}=-0.2)$ and a positive correlation with $\mathrm{P}(\mathrm{r}=0.2), \mathrm{NO}_{3}{ }^{-}(\mathrm{r}=0.2)$ and $\mathrm{rBC}(\mathrm{r}=0.2$, Fig. 2(b)). There are more high positive correlations between $\mathrm{Cl}^{-}, \mathrm{K}^{+}, \mathrm{Zn}, \mathrm{Pb}, \mathrm{Na}^{+}, \mathrm{Br}, \mathrm{Ni}, \mathrm{P}$ and $\mathrm{Fe}$ (Fig. 2(b)), which indicates that these compounds have similar sources.

The analysed mass concentration of qUFP is dominated by $\mathrm{rBC}\left(2.78 \mu \mathrm{g} \mathrm{m}^{-3}\right)$ and ions $\left(0.97 \mu \mathrm{g} \mathrm{m}^{-3}\right)$, mainly $\mathrm{SO}_{4}{ }^{2-}$ $\left(0.61 \mu \mathrm{g} \mathrm{m}^{-3}\right.$, Table 2$)$. This result is similar to results found in Los Angeles beach harbor, where it was $\mathrm{SO}_{4}{ }^{2-}$ that dominated qUFP mass concentration (rBC was not analysed; $\mathrm{Hu}$ et al., 2008). The main source of $\mathrm{SO}_{4}{ }^{2-}$ in Los
Angeles was considered bunker fuel combustion from ships (Arhami et al., 2009). In outdoor environments in MASP, $\mathrm{SO}_{4}{ }^{2-}$ is the ion with highest concentration in $\mathrm{PM}_{2.5}$ (Ynoue and Andrade, 2004; Miranda et al., 2012; Vieira-filho et al., $2016 \mathrm{~b}$ ) and it shows a modal peak of the mass concentration in particles around $0.3 \mu \mathrm{m}$ diameter (Ynoue and Andrade, 2004; Vieira-filho et al., 2016a). The residence with the highest concentration of $\mathrm{SO}_{4}{ }^{2-}$ is the residence \#14. It is located very close to the Rebouças Avenue, a large avenue with intense vehicular traffic. The trace elements contributing mostly to qUFP are Si, followed by Fe and Zn (Table 2). The high concentration of $\mathrm{Si}$ in the residence \#60 is probably due to nearby construction works happening during the sample collection. This residence also has very large concentrations of $\mathrm{K}^{+}, \mathrm{Cl}^{-}$and $\mathrm{Cr}$. The ions $\mathrm{K}^{+}$and $\mathrm{Cl}^{-}$have a strong positive correlation (Fig. 2(b)) which may indicate biomass burning (Ynoue and Andrade, 2004). In this residence, they are most likely associated with the cooking of fried eggs for lunch. The Cr likely originates from paint (Tan et al., 2013) from both the construction site and the residence itself. The residence $\# 5$, which shows the maximum $\mathrm{Fe}$, also has a maximum in $\mathrm{Ni}$ and $\mathrm{Br}$, which can be associated with vehicular emissions: the residence is very close to Consolação Avenue and Júlio de Mesquita Viaduct, both very busy road impacted by buses and passenger cars. The $\mathrm{Ni}$ and $\mathrm{Cu}$ and were the compounds of indoor qUFP that have a mass concentration (Table 2) similar to found in outdoor $\mathrm{PM}_{2.5}$ in MASP: $1.0 \pm 1.0$ and 10 $\pm 8 \mathrm{ng} \mathrm{m}^{-3}$, respectively (Andrade et al., 2012). For Cu, this occurs basically due to the maximum in residence \#56. This residence is far from urbanized area, and the fungicides can be a source for qUFP with high $\mathrm{Cu}$ concentration. Other residences, as number $\# 5, \# 13$ and $\# 60$, have a high concentration of heavy metals as $\mathrm{Ni}, \mathrm{Pb}$, and $\mathrm{Cr}$, respectively (Table 2 ).
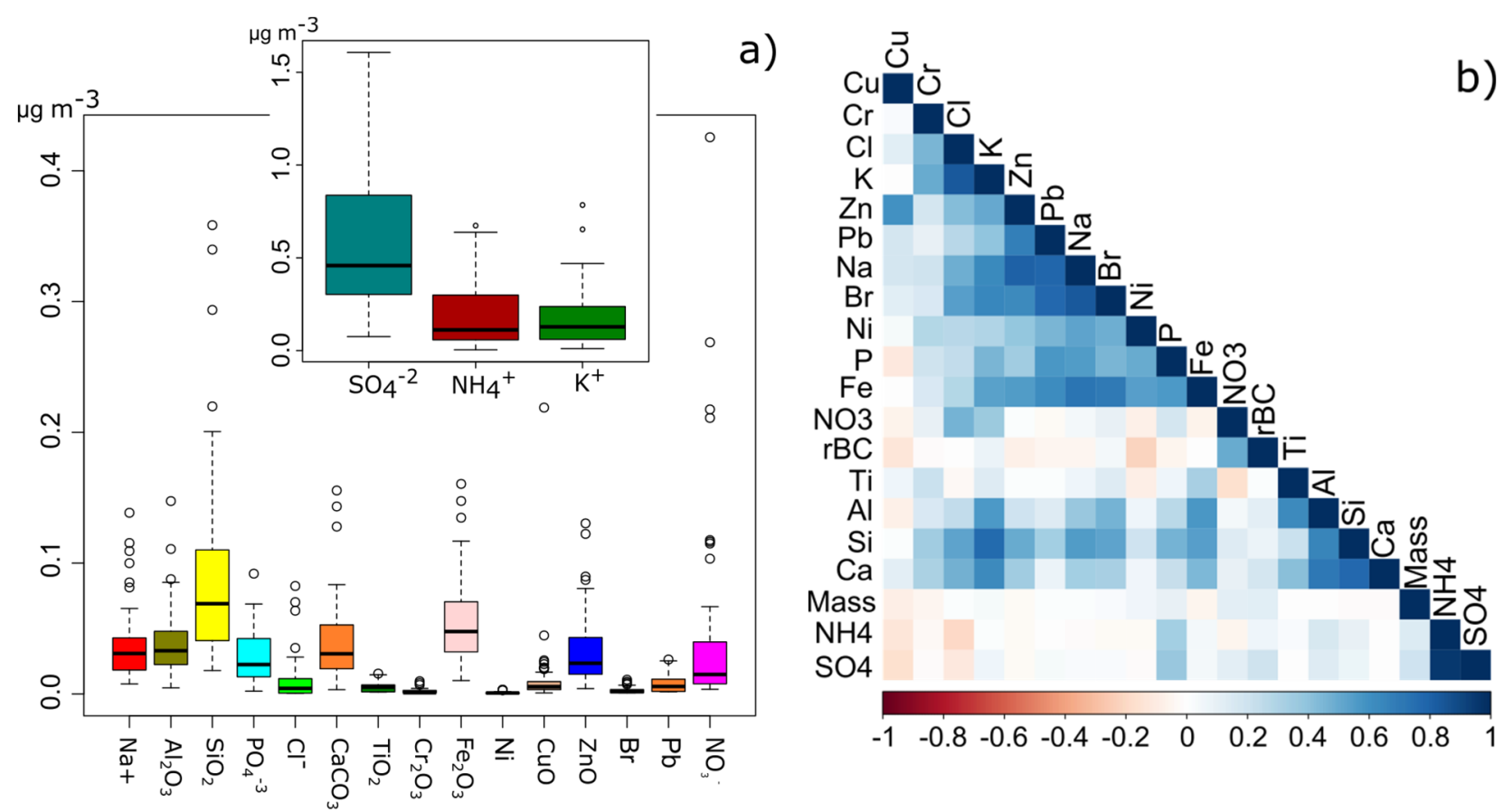

Fig. 2. (a) Ions and trace elements present in qUFP and (b) the Pearson correlation between them in elderly residences in MASP. 
The acidity of aerosol particles is a parameter obtained not by direct $\mathrm{pH}$ measurements, but by proxies based on ion balances and molar ratios of ions, involving the equilibrium relationships of the major ions present in the water-soluble fraction (Vieira-Filho et al., 2016; Weber et al., 2016; Shi et al., 2017; Ding et al., 2019). The importance of aerosol acidity is directly related to its effects on human health (Wyzga and Folinsbee, 1995; Raizenne et al., 1996; Rohr and Wyzga, 2012), as well as being a parameter affecting fundamental atmospheric physical-chemical processes in the formation of secondary aerosol and also in the formation and growth of cloud condensation nuclei. Aerosol acidity affects both the gas-aerosol partition of semi-volatile and volatile species as well as thermodynamic and kinetic parameters of acidcatalysed reactions (Vieira-Filho et al., 2016; Shi et al., 2017; Ding et al., 2019). In order to evaluate the acidity of the qUFP, we analysed the stoichiometry between ammonium $\left(\mathrm{NH}_{4}^{+}\right)$and on the one hand sulphate $\left(\mathrm{SO}_{4}^{-2}\right)$ and sulphate plus nitrate $\left(\mathrm{SO}_{4}{ }^{-2}+\mathrm{NO}_{3}{ }^{-}\right)$on the other. Ammonium and sulphate in qUFP have a slope of 2.2 (Fig. 3(a)), indicating a good neutralization from sulfuric acid by ammonia. However, the ammonia is not quite enough to neutralize both sulfuric and nitric acid (Fig. 3(b)) and to produce the respective ammonium salts. This pattern indicates that less acidity was present in indoor qUFP than found in outdoor $\mathrm{PM}_{1}(<1 \mu \mathrm{m}$; Vieira-filho et al., 2016a). The ammonium linear fit versus sulphate plus nitrate $\left(\mathrm{SO}_{4}{ }^{-2}+\mathrm{NO}_{3}{ }^{-}\right)$has a more consistent determination coefficient in indoor qUFP $\left(\mathrm{R}^{2}=0.76\right)$ than outdoor $\mathrm{PM}_{1}\left(\mathrm{R}^{2}=0.45\right.$; Vieira-filho et al., 2016a). This good relation between ammonium and sulphate and nitrate also indicates that secondary inorganic aerosol mass is produced effectively by the reaction between ammonia and sulphuric acid and nitrate acid from the gas phase.

\section{Chemical Mass Balance and Cluster Analysis of qUFP}

We use cluster analyses to classify the elderly residences by trace elements, ions and mass concentrations. The best fit of the cluster analyses grouped the residences into 2 groups framed in red and blue in Fig. 4, respectively. The location of the residences is presented in Fig. 1, where the red and blue colours represent the residences of the Groups 1 and 2, respectively. We also calculated the mass balances for all the residences and for both groups in order to understand the differences between these groups (Fig. 5). The mass balance shows a predominance of $\mathrm{rBC}$ in the Group 2, which indicates a stronger relationship between indoor qUFP and outdoor sources than in Group 1 because $\mathrm{rBc}$ is usually associated with vehicular emissions (Sánchez-Ccoyllo et al., 2009, Andrade et al., 2012). All the residences with a maximum in trace elements (Table 2) are in the Group 1 (Fig. 4). The mass concentration of the ions $\mathrm{NH}_{4}{ }^{+}$and $\mathrm{SO}_{4}{ }^{-2}$ and of the $\mathrm{K}^{+}$ is higher in the Group 1 than Group 2 (Fig. 5).

The mass concentration of the groups is an average of the mass concentration of all residences in that group. The difference of mass concentration between the groups is $2.3 \mu \mathrm{g} \mathrm{m}^{-3}$, Group 2 has $18.9 \%$ higher mass concentration $\left(12.2 \mu \mathrm{g} \mathrm{m}^{-3}\right)$ than Group $1\left(9.9 \mu \mathrm{g} \mathrm{m}^{-3}\right)$, however is a nonsignificant difference ( $\mathrm{p}$-value over 0.36). The Group 2 also present higher average of outdoor temperature, relative humidity, wind speed and, in particular, the precipitation than in Group 1 (SI Table S5). More precipitation during the measurements should cause a drop in the mass concentration in Group 2. However, it is the group with more mass concentration and with a predominance of $\mathrm{rBC}$ (Fig. 5). In this context and due to the outdoor sources, we can assume that the localization of the residences can have a stronger influence in the mass concentration and composition of indoor qUFP than the weather conditions during the measurements. This is more evident for the residences in Group 2.

\section{Sources of $q U F P$}

Through the PMF we identified 6 factors that represent 7, 21, $7,57,5$ and $3 \%$ of the analysed mass concentration of qUFP, respectively (Fig. 6). The first factor has high contributions of $\mathrm{Na}, \mathrm{Zn}, \mathrm{Cu}$, and $\mathrm{Pb}$, elements which are positively correlated to each other (Fig. 2(b)). Although $\mathrm{Zn}$ and $\mathrm{Cu}$ are typical
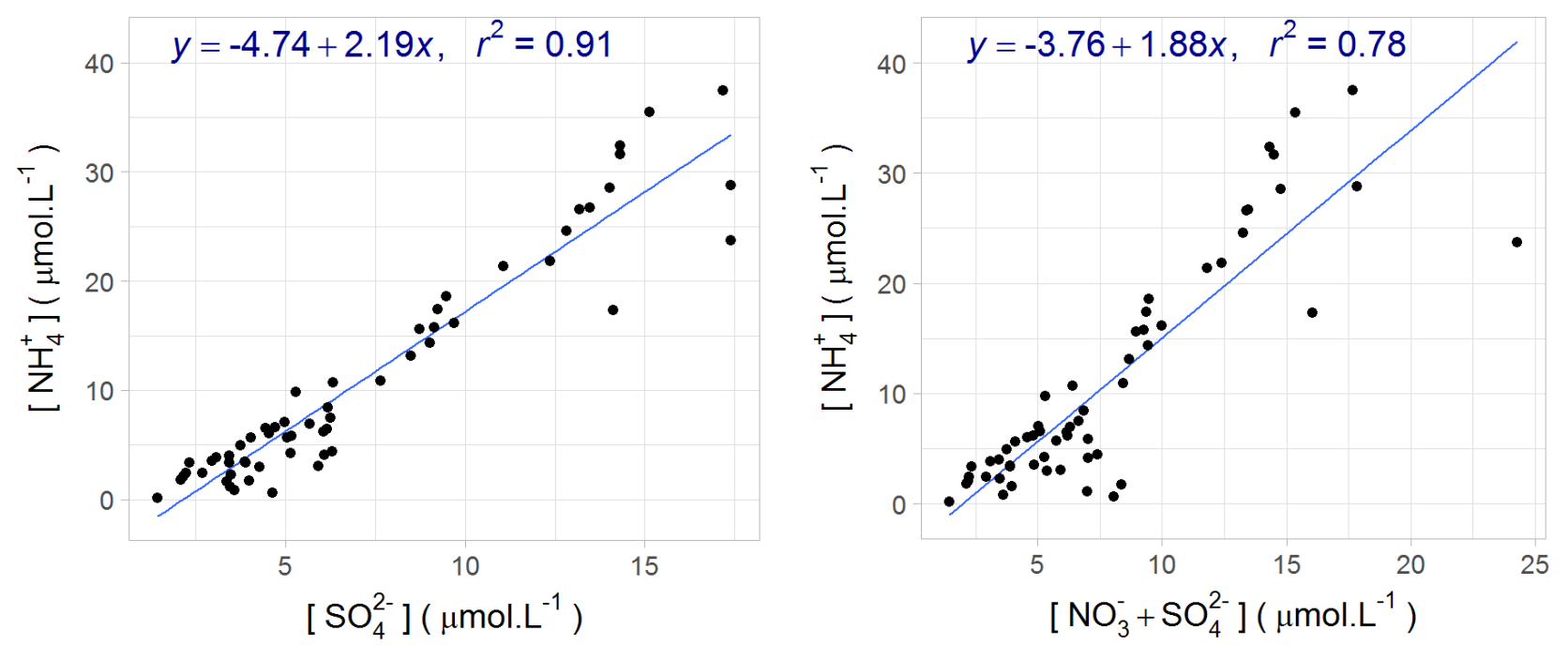

Fig. 3. Stoichiometry ratios $\left(\mu \mathrm{mol} \mathrm{L} \mathrm{L}^{-1}\right)$ between (a) ammonium and sulfate and (b) sulfate plus nitrate for qUFP in elderly residences in MASP. 


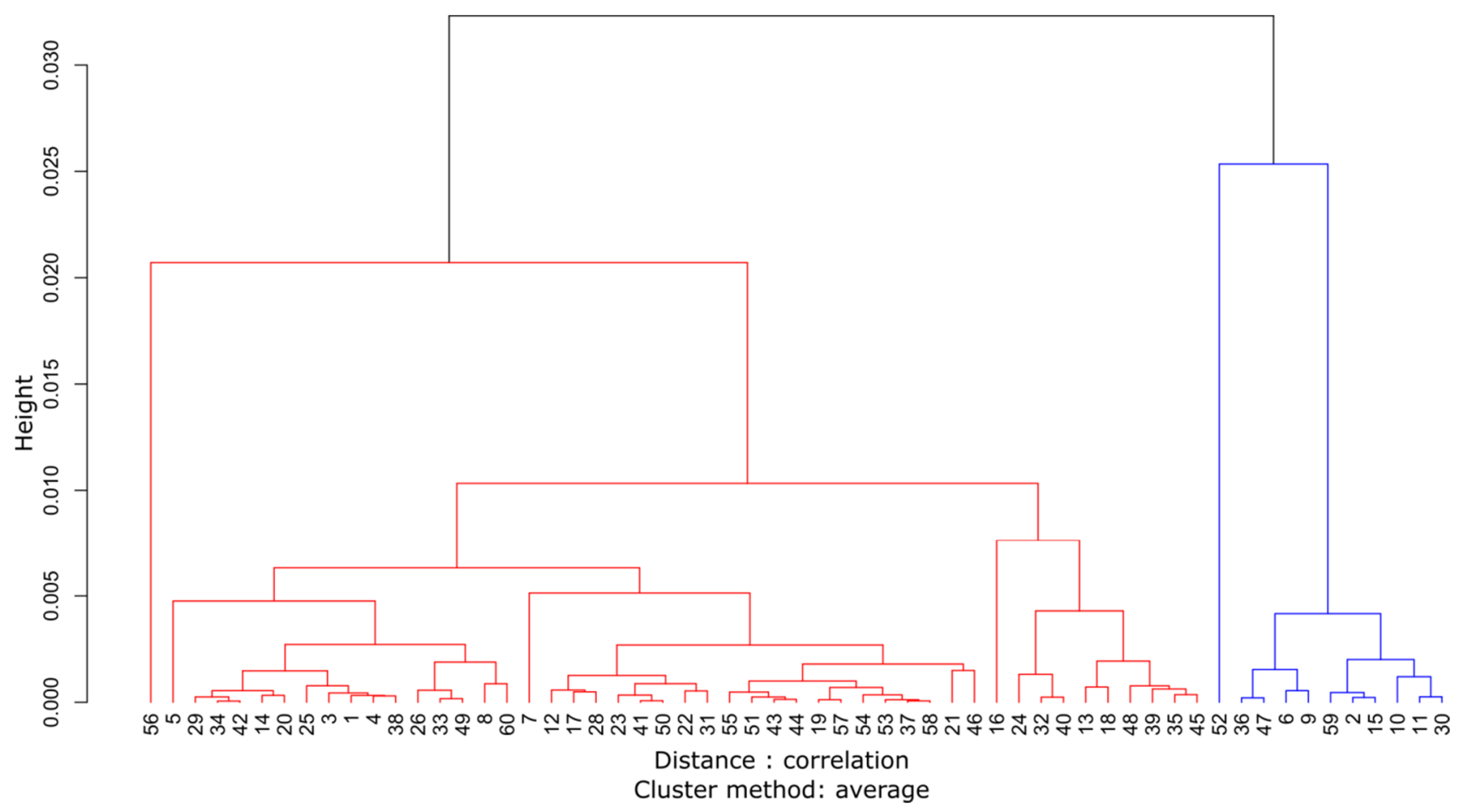

Fig. 4. Clusters dendrogram of the residences in accordance with their mass concentration, ions and trace elements composition. The two clusters were determined with an approximately unbiased $p$-value of 0.95 .

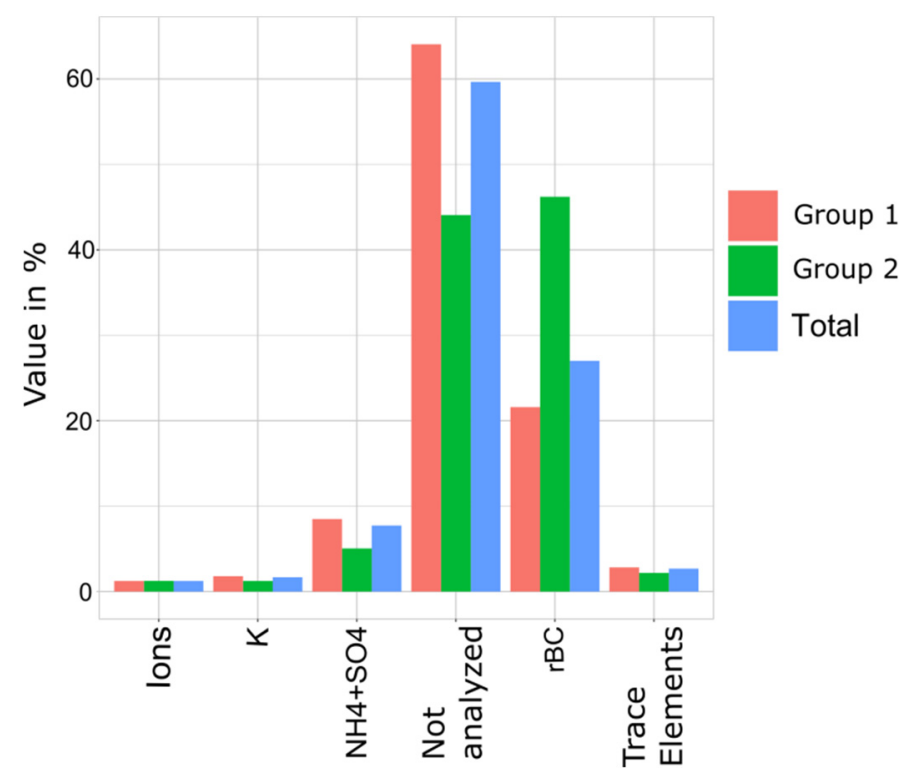

Fig. 5. Mass balance of qUFP with the proportions of ions (separated in 3 parts: $\mathrm{K}^{+}, \mathrm{NH}_{4}{ }^{+}+\mathrm{SO}_{4}{ }^{2-}$ and others ions $\left(\mathrm{Ca}^{2+}\right.$, $\left.\mathrm{Na}^{+}, \mathrm{Cl}^{-}, \mathrm{NO}_{3}^{-}\right)$), trace elements, black carbon ( $\mathrm{rBC}$ - from Segalin et al., 2016) and compound not analyzed in this work, for all the residences (Total) and for the two groups generated for cluster analysis in Fig. 4.

vehicular source markers (Andrade et al., 2012), they also have indoor sources for qUFP, usually wall paints (Viena $e t$ al., 2014), and $\mathrm{Pb}$ is also a component of wall paint, mostly in old residences (Beauchemin et al., 2011), then for this study Factor 1 is wall paint. Factor 2 is considered as secondary inorganic aerosol because of the high concentrations of ions $\mathrm{NH}_{4}^{+}$and $\mathrm{SO}_{4}{ }^{2-}$, which indicate a large contribution of secondary inorganic aerosol production to qUFP, as described in Section 3.1. Measurements in tunnels in MASP showed higher concentrations of $\mathrm{NH}_{4}{ }^{+}$and $\mathrm{SO}_{4}{ }^{2-}$ in fine particles within the tunnels than outside, indicating a vehicular contribution to the production of sulphate and ammonium particles in urbanized areas (Vieira-filho et al., 2016b). In the outdoor air in MASP, $\mathrm{SO}_{4}{ }^{2-}$ presented a modal peak of the mass concentration distribution around $0.3 \mu \mathrm{m}$ diameter and its source was $\mathrm{SO}_{2}$ from fuel burning by vehicles 
(Ynoue and Andrade, 2004; Vieira-filho et al., 2016a). Also, in outdoor Los Angeles atmosphere, the $\mathrm{SO}_{4}{ }^{2-}$ in qUFP was considered originating from fuel combustion (Arhami et al., 2009). Factor 3 is predominantly $\mathrm{Al}, \mathrm{Ca}^{2+}, \mathrm{Si}, \mathrm{Fe}$ and $\mathrm{Ti}$, indicating a soil- and construction- related factor (Andrade et al., 2012). Factor 4 is from vehicular emissions since it is dominated by rBC and nitrate (Sánchez-Ccoyllo et al., 2009; Andrade et al., 2012). Factor 5 is predominantly $\mathrm{K}+$ and $\mathrm{Cl}^{-}$ (Fig. 6). These ions indicate biomass burning (Ynoue and Andrade, 2004) and $\mathrm{Cl}^{-}$is also considered to be an indoor source for qUFP (Viana et al., 2014), this factor likely indicates indoor biomass burning. Based on this, Factor 5 is considered cooking process source of qUFP. In Factor 6, there are high percentages of the $\mathrm{P}, \mathrm{Ni}, \mathrm{Fe}$ and $\mathrm{Pb}$. In the MASP air, $\mathrm{Ni}, \mathrm{Fe}$, and $\mathrm{Pb}$ in fine particles are associated with industrial emissions (Castanho and Artaxo, 2001). Factor 6 is probably representing the qUFP produced in industrial process that penetrates into the residences. The particles inside the residences can be produced there or may came from outside through the windows or doors. In Brazil, the windows are generally always open due to the heat in the summer and the rather mild winters. Factor 1 is a wall paint source, therefore a source of indoor origin. Factor 2 is a secondary inorganic aerosol, Factor 3 is a soil and construction source, Factor 4 is vehicular emissions, all of which are sources of outdoor origin. Factor 5 is cooking (source of
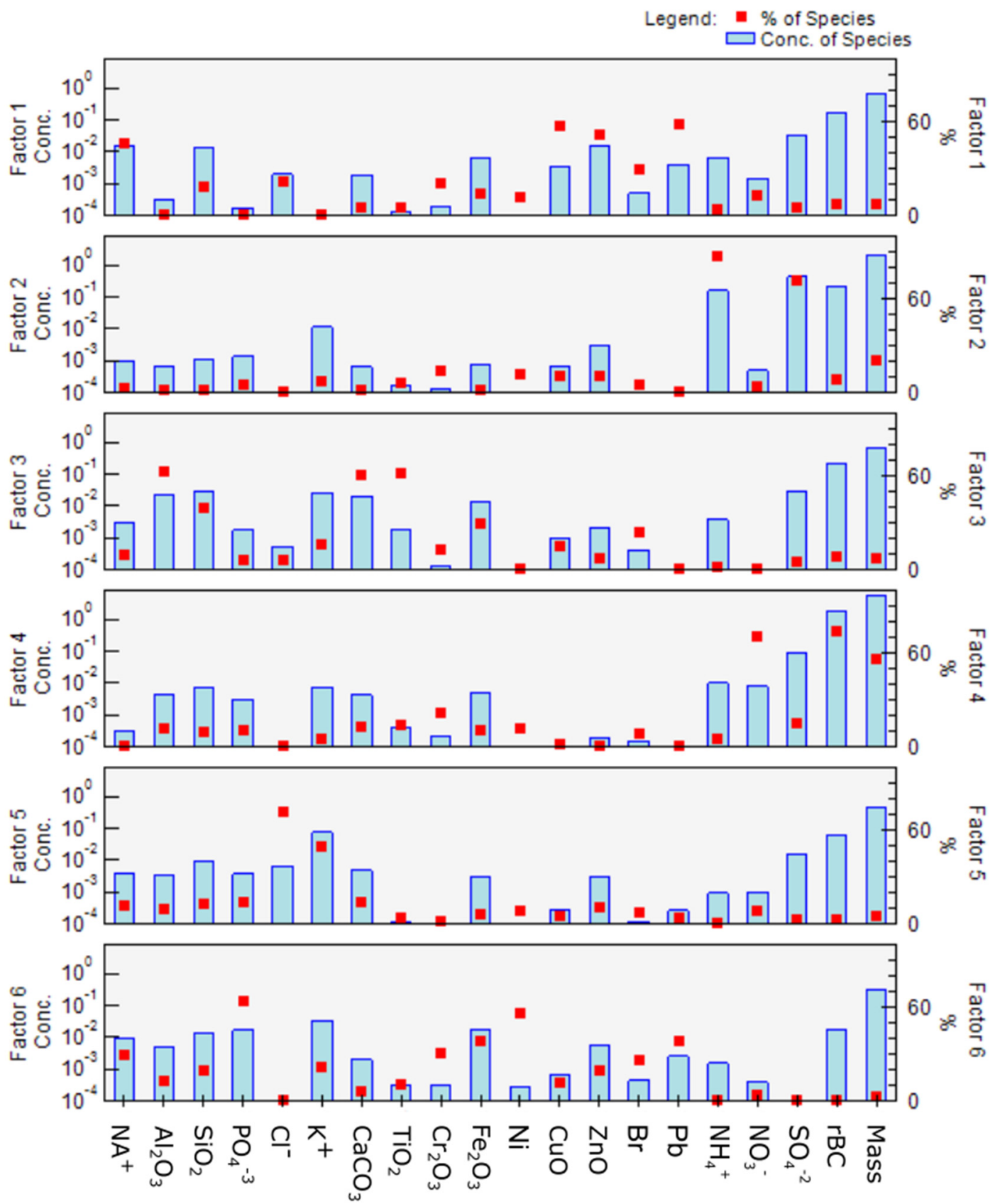

Fig. 6. The result of PMF analysis (6 factors) of mass concentrations of trace elements and ions of qUFP sampled in elderly residences in MASP. Blue bars indicate the mass concentrations and red dots the relative contributions to the total mass. 
indoor origin) and Factor 6 is an industrial source (source of outdoor origin). According to this analysis, the qUFP in elderly residence originated from 2 sources of indoor origin (Factors 1 and 5) and 4 sources of outdoor origin (Factors 2, 3,4 and 6). Since the factors represent 7, 21, 7, 57, 5 and $3 \%$ of the analysed mass concentration of qUFP, the major mass concentration $(88 \%)$ of qUFP is associated with outdoor sources, mainly vehicular emission (57\%, Factor 4$)$. In the MASP, the major source of outdoor fine particles is attributable to vehicular emission due to more than 8.39 million vehicles (CETESB, 2016; DETRAN, 2017). The vehicular emission in the MASP contributes directly to $37 \%$ of the $\mathrm{PM}_{2.5}$ concentration. Further, there is an indirect contribution to the production of secondary aerosol mass $\left(51 \%\right.$ of $\mathrm{PM}_{2.5}$, CETESB, 2016). Outdoor $\mathrm{rBC}$ is produced by vehicles predominantly as UFP (Ynoue and Andrade, 2004) and these particles are small enough to penetrate easily into indoor environments (Abt et al., 2000) and so contribute to the mass concentration of qUFP particles in elderly residences $(26 \%$, Segalin et al., 2016).

\section{Respiratory Deposition Doses (RDD) of qUFP and rBC Mass Concentrations}

Fig. 7 shows the RDD of qUFP and rBC for 24 hours in head airways, tracheobronchial and alveolar regions, for men and women during light exercises and seated position. The RDD is higher for men than for women and higher during light exercise than in a seated position of the persons. The same pattern occurs for RDD in the total respiratory tract because the tidal volume is bigger for men than for women, and it is bigger during light exercises (Hinds, 1999; Azarmi et al., 2016; Segalin et al., 2017). The RDD of qUFP and $\mathrm{rBC}$ in tracheobronchial and alveolar regions are similar for both male and female and light exercise and seated positions, with a little more RDD in the tracheobronchial region than in the alveolar region. The maximum RDD occurs in men during light exercise and in the tracheobronchial region. The RDD total is higher for coarse particles than for qUFP (Segalin, et al., 2017), however, the RDD of qUFP is higher in tracheobronchial and alveolar parts than in the head. The latter poses a larger health risk because these particles can translocate from the alveoli to the bloodstream and eventually cause damage to other parts of the body such brain and heart (Elder et al., 2006; Heal et al., 2012).

\section{SUMMARY AND CONCLUSIONS}

The goal of this project was to characterize the ion and trace elements concentrations in qUFP, to identify the sources of the qUFP inside elderly residences and to estimate of RDD of the qUFP and the $\mathrm{rBC}$ in different parts of the respiratory tract. In the best of our knowledge, this is the first research to study the chemical characteristics of the qUFP in elderly residences in a Latin American megacity. We measured qUFP in 59 residences of elderly with the PCIS in the MASP. The measurements were made during 24 hours, once in each residence, during different days, except in one residence where 2 samples were taken because 2 elderly live there. Overall, a total of 60 samples were analysed.

The predominant ions in indoor qUFP were $\mathrm{SO}_{4}{ }^{2-}$ and $\mathrm{NH}_{4}{ }^{+}$and the major trace elements were $\mathrm{Si}$ and Fe. Some residences had a high concentration of heavy metals such as $\mathrm{Cu}, \mathrm{Pb}, \mathrm{Ni}$ and $\mathrm{Cr}$ that pose a significant health risk. There was a good neutralization of sulfuric acid by ammoniaproducing secondary inorganic aerosols that form qUFP. However, the ammonia was not sufficient to neutralize both sulfuric and nitric acids and to produce respective amounts of ammonium salts.

Since our measurements were made in different locations and days, we classified the residences in 2 groups by cluster analyses. The mass balance of these groups shows a predominance of rBC in Group 2 and of $\mathrm{NH}_{4}{ }^{+}, \mathrm{SO}_{4}{ }^{2-}$ and $\mathrm{K}^{+}$

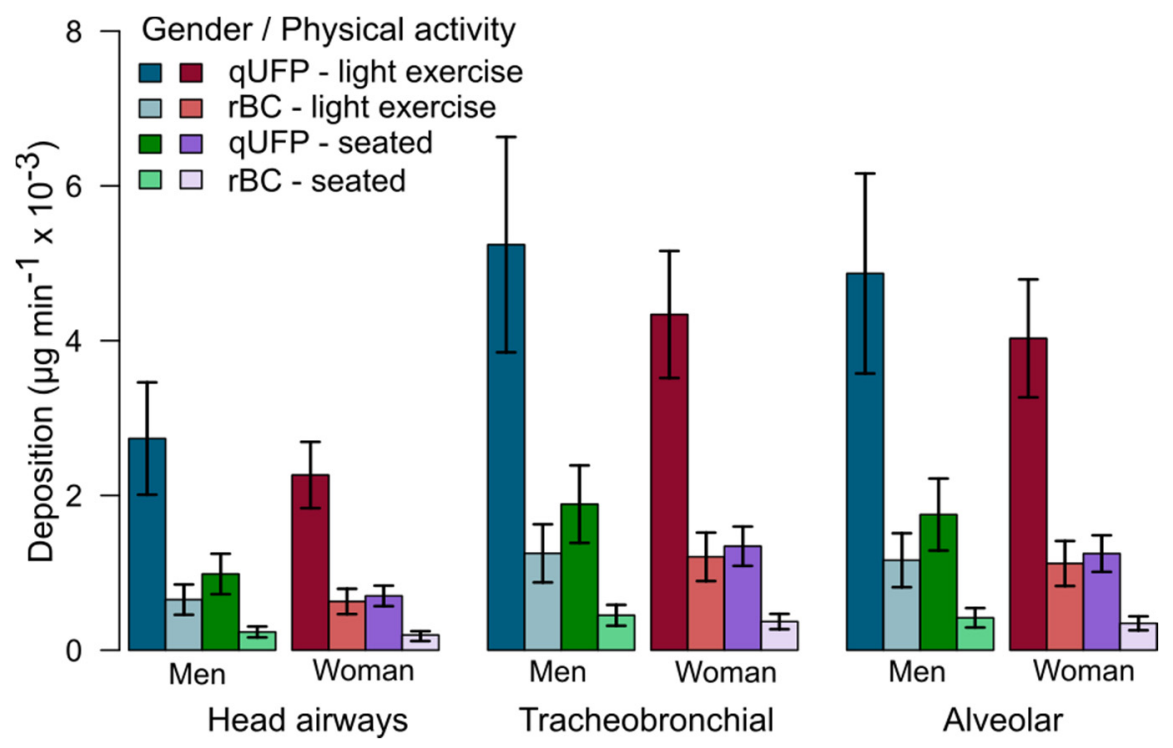

Fig. 7. Rates deposition doses (RDD) of qUFP and its proportion of black carbon (rBC - present in qUFP from Segalin et al., 2016) in different regions of the respiratory tract for men and women during light exercises and seated position during 24 hours. 
in Group 1. The precipitation and the number of days with precipitation were higher in the residences in the Group 2 than Group 1. However, the mass concentration was $18.8 \%$ higher in Group 2 than in Group 1. We conclude that the location of the residences within the MASP plays a larger role in the mass concentration and chemical balance of indoor qUFP in elderly residence than the weather conditions.

We found 2 indoor sources of qUFP inside the elderly residences, wall painting $(7 \%)$ and cooking $(5 \%)$, but the main contribution to the mass concentration of qUFP was associated with the outdoor sources, oil and construction $(7 \%)$, industry (3\%), secondary inorganic aerosol (21\%) and mainly vehicular emission (57\%).

The RDD of qUFP and $\mathrm{rBC}$ were higher in men than in women, higher during light exercise than in the seated position, and higher in the tracheobronchial region than in alveolar and head regions. Higher RDD on the deeper part of respiratory tract causes more damage to the health than deposition in the head.

The above finding confirms that elderly is breathing the air with abundance of qUFPs and a very high mass concentration of toxic metals in some residences, which is mainly due to the high number of outdoor vehicles on roads around their residences. The necessity of a better trafficrelated emission control in MASP has been already discussed by many authors. Since the elderly spend most of their daily time inside their residences and considering that demographic projections suggest an increase in their numbers in future, further efforts are needed to improve indoor air quality.

\section{ACKNOWLEDGEMENTS}

We thank the FAPESP (Foundation for Research Support of the State of São Paulo) for funded the project 2010/10189-5: Human biometeorology: Analysis of the environmental variable effects (weather, thermal comfort and air pollution) and climate change in geriatric population of São Paulo, and UGPN (University Global Partnership Network) for funding the projects BIOBURN (Towards the Treatment of Aerosol Emissions from Biomass Burning in Chemical Transport Models through a case study in the Metropolitan Area of São Paulo) and NEST-SEAS (NextGeneration Environmental Sensing for Local To Global Scale Health Impact Assessment), both supporting this work. Bruna Segalin thanks the DAAD (German Academic Exchange Service) and the CNPq (National Council for Scientific and Technological Development) for the grants provided. We also thank the University of São Paulo, University of Surrey and University of Münster for supporting this research and Kaonan Micadei, Rosana Astolfo and Hanna Leona Lokys for useful discussions. Last not least we appreciate the time and effort of the anonymous reviewers to help improve this manuscript.

\section{SUPPLEMENTARY MATERIAL}

Supplementary data associated with this article can be found in the online version at http://www.aaqr.org.

\section{REFERENCES}

Abt, E., Suh, H.H., Catalano, P. and Koutrakis, P. (2000). Relative contribution of outdoor and indoor particle sources to indoor concentrations. Environ. Sci. Technol. 34: 3579-3587.

Afshari, A., Matson, U. and Ekberg, L.E. (2005). Characterization of indoor sources of fine and ultrafine particles: A study conducted in a full-scale chamber. Indoor Air 15: 141-150.

Al-Dabbous, A.N. and Kumar, P. (2015). Source apportionment of airborne nanoparticles in a Middle Eastern city using positive matrix factorization. Environ. Sci. Processes Impacts 17: 802-812.

Alessandri, M.R. and Maeda, M.D. (2011) Informes Urbanos: Cresce o número de idosos. Prefeitura de São Paulo, Secretaria Municipal de Desenvolvimento Urbano de São Paulo, pp. 3. http://smdu.prefeitura.sp.gov.br/infor mes_urbanos/pdf/5.pdf, Last Access: 10 January 2016.

Amato, F., Rivas, I., Viana, M., Moreno, T., Bouso, L., Reche, C., Àlvarez-Pedrerol M., Alastuey A., Sunyer, J. and Querol, X. (2014). Sources of indoor and outdoor $\mathrm{PM}_{2.5}$ concentrations in primary schools. Sci. Total Environ. 490: 757-765.

Andrade, M.F., Miranda, R.M., Fornaro, A., Kerr, A., Oyama, B., Andre, P.A. and Saldiva, P. (2012). Vehicle emissions and $\mathrm{PM}_{2.5}$ mass concentrations in six Brazilian cities. Air Qual. Atmos. Health 5: 79-88.

Andrade, M.d.F., Kumar, P., de Freitas, E.D., Ynoue, R.Y., Martins, J., Martins, L.D., Nogueira, T., Perez-Martinez, P., de Miranda, R.M., Albuquerque, T., Gonçalves, F.L.T., Oyama, B. and Zhang, Y. (2017). Air quality in the megacity of São Paulo: Evolution over the last 30 years and future perspectives. Atmos. Environ. 159: 66-82.

Arana, A.A. (2014). Aerossóis Atmosféricos na Amazônia: Composição elementar orgânica e inorgânica em regiões com diferentes usos do solo. $\mathrm{PhD}$ thesis, Instituto Nacional de Pesquisas da Amazônia, Universidade do Estado do Amazonas, Manaus.

Arhami, M., Sillanpää, M., Hu, S., Olson, M.R., Schauer, J.J. and Sioutas, C. (2009). Size-segregated inorganic and organic components of PM in the communities of the Los Angeles Harbor. Aerosol Sci. Technol. 43: 145-160.

Attfield, M.D. and Costello, J. (2004). Quantitative exposureresponse for silica dust and lung cancer in Vermont granite workers. Am. J. Ind. Med. 45: 129-138.

Azarmi, F. and Kumar, P. (2016). Ambient exposure to coarse and fine particle emissions from building demolition. Atmos. Environ. 137: 62-79.

Beauchemin, S., MacLean, L.C. and Rasmussen, P.E. (2011). Lead speciation in indoor dust: A case study to assess old paint contribution in a Canadian urban house. Environ. Geochem. Health 33: 343-352.

Beuck, H., Quass, U., Klemm, O. and Kuhlbusch, T.A.J. (2011). Assessment of sea salt and mineral dust contributions to $\mathrm{PM}_{10}$ in NW Germany using tracer models and positive matrix factorization. Atmos. Environ. 45: 5813-5821.

Bhangar, S., Mullen, N., Hering, S., Kreisberg N. and 
Nazarof, W. (2011) Ultrafine particle concentrations and exposures in seven residences in northern California. Indoor Air 21: 132-144.

Brown, S.G., Eberly, S., Paatero, P. and Norris, G.A. (2015). Methods for estimating uncertainty in PMF solutions: Examples with ambient air and water quality data and guidance on reporting PMF results. Sci. Total Environ. 518: 626-635.

Campen, M.J., Nolan, J.P., Schladweiler, M.C., Kodavanti, U.P., Evansky, P.A., Costa, D.L. and Watkinson, W.P. (2001). Cardiovascular and thermoregulatory effects of inhaled PM-associated transition metals: A potential interaction between nickel and vanadium sulphate. Toxicol. Sci. 64: 243-252.

Castanho, A.D. and Artaxo, P. (2001). Wintertime and summertime São Paulo aerosol source apportionment study. Atmos. Environ. 35: 4889-4902.

CETESB (2016). Companhia Ambiental do Estado de São Paulo. Emissões veiculares no Estado de São Paulo 2015. 1-145. http://veicular.cetesb.sp.gov.br/relatorios-e-publi cacoes/, Last Access: 10 January 2017.

Chang, C.C., Hwang, J.S., Chan, C.C. and Cheng, T.J. (2007). Interaction effects of ultrafine carbon black with iron and nickel on heart rate variability in spontaneously hypertensive rats. Environ. Health Perspect. 115: 10121017.

Chatterji, S., Byles, J., Cutler, D., Seeman, T. and Verdes, E. (2015) Health, functioning, and disability in older adults: Present status and future implications. Lancet 385 : 563-575.

Chueinta, W., Hopke, P.K. and Paatero, P. (2000). Investigation of sources of atmospheric aerosol at urban and suburban residential areas in Thailand by positive matrix factorization. Atmos. Environ. 34: 3319-3329.

Cichocki, A., Zdunek, R., Phan, A.H. and Amari, S.I. (2009). Nonnegative matrix and tensor factorizations: applications to exploratory multi-way data analysis and blind source separation. John Wiley \& Sons, New York, USA, p. 473. ISBN 9780470746660.

DETRAN (2017). Departamento Estadual de Trânsito de São Paulo. Gabinete de planejamento e gestão. http://www.detran.sp.gov.br/wps/portal/portaldetran/detr an/estatisticastransito/sa-frotaveiculos/, Last Access: 09 March 2017.

Ding. J., Zhao, P., Su, J., Dong, Q., Du, X. and Zhang, Y. (2019). Aerosol pH and its driving factors in Beijing, Atmos. Chem. Phys. 19: 7939-7954.

Elder, A., Gelein, R., Silva, V., Feikert, T., Opanashuk, L., Carter, J., Potter, R., Maynard, A., Ito, Y., Finkelstein, J. and Oberdörster, G. (2006). Translocation of inhaled ultrafine manganese oxide particles to the central nervous system. Environ. Health Perspect. 114: 1172-1178.

Folstein, M.F., Folstein, S.E. and McHugh, P.R. (1975). "Mini-mental state": A practical method for grading the cognitive state of patients for the clinician. J. Psychiatr. Res. 12: 189-198.

Gietl, J.K. and Klemm, O. (2009). Source identification of size-segregated aerosol in Münster, Germany, by factor analysis. Aerosol Sci. Technol. 43: 828-837.
Goel, A. and Kumar, P. (2015). Zone of influence for particle number concentrations at signalised traffic intersections. Atmos. Environ. 123: 25-38.

Guralnik, J.M., Simonsick, E.M., Ferrucci, L., Glynn, R.J., Berkman, L.F., Blazer, D.G., Scherr, P.A. and Wallace, R.B. (1994). A short physical performance battery assessing lower extremity function: Association with selfreported disability and prediction of mortality and nursing home admission. J. Gerontol. 49: M85-M94.

Heal, M.R., Kumar, P. and Harrison, R.M. (2012). Particles, air quality, policy and health. Chem. Soc. Rev. 41: 66066630.

Hinds, W.C. (1999). Aerosol technology: Properties, behaviour and measurement of airborne particles. Second ed. John Wiley \& Sons, USA, p. 483.

Holguín, F., Téllez-Rojo, M.M., Hernández, M., Cortez, M., Chow, J.C., Watson, J.G., Mannino, D. and Romieu, I. (2003). Air pollution and heart rate variability among the elderly in Mexico City. Epidemiology 14: 521-527.

Hu, S., Polidori, A., Arhami, M., Shafer, M.M., Schauer, J.J., Cho, A. and Sioutas, C. (2008). Redox activity and chemical speciation of size fractioned PM in the communities of the Los Angeles-Long Beach harbor. Atmos. Chem. Phys. 8: 6439-6451.

Hueglin, C., Gehrig, R., Baltensperger, U., Gysel, M., Monn, C. and Vonmont, H. (2005). Chemical characterisation of $\mathrm{PM}_{2.5}, \mathrm{PM}_{10}$ and coarse particles at urban, near-city and rural sites in Switzerland. Atmos. Environ. 39: 637-651.

Hussein, T., Glytsos, T., Ondráček, J., Dohányosová, P., Ždímal, V., Hämeri, K., Lazaridis, M., Smolík, J. and Kulmala, M. (2006) Particle size characterization and emission rates during indoor activities in a house. Atmos. Environ. 40: 4285-4307.

IBGE (2016). Instituto Brasileiro de Geografia e Estatística. (Brazilian Institute of Geography and Statistics). http://cod.ibge.gov.br/QHF, Last Access: 28 June 2016.

Jansen, K.L., Larson, T.V., Koenig, J.Q., Mar, T.F., Fields, C., Stewart, J. and Lippmann, M. (2005). Associations between health effects and particulate matter and black carbon in subjects with respiratory disease. Environ. Health Perspect. 113: 1741-1746.

Kamens, R., Lee, C.T., Wiener, R. and Leith, D. (1991). A study of characterize indoor particles in three nonsmoking homes. Atmos. Environ. 25: 939-948.

Khan, M.F., Latif, M.T., Saw, W.H., Amil, N., Nadzir, M.S.M., Sahani, M., Tahir, N.M. and Chung, J.X. (2016). Fine particulate matter in the tropical environment: monsoonal effects, source apportionment, and health risk assessment. Atmos. Chem. Phys. 16: 597-617.

Kotz, J.C. and Purcell, K.F. (1987). Naming Coordination Compounds. In Chemistry \& Chemical Reactivity, Saunders College Publishing, USA, p. 962.

Kumar, P., de Fatima Andrade, M., Ynoue, R.Y., Fornaro, A., de Freitas, E.D., Martins, J., Martins, L.D., Albuquerque, T., Zhang, Y. and Morawska, L. (2016). New directions: From biofuels to wood stoves: The modern and ancient air quality challenges in the megacity of São Paulo. Atmos. Environ. 140: 364-369.

Kumar, P., Fennell, P.S., Hayhurst, A.N. and Britter, R.E. 
(2009). Street versus rooftop level concentrations of fine particles in a Cambridge street canyon. Boundary Layer Meteorol. 131: 3-18.

Kumar, P., Robins, A., Vardoulakis, S. and Britter, R. (2010). A review of the characteristics of nanoparticles in the urban atmosphere and the prospects for developing regulatory control. Atmos. Environ. 44: 5035-5052.

Kumar, P., Pirjola, L., Ketzel, M. and Harrison, R.M. (2013). Nanoparticle emissions from 11 non-vehicle exhaust sources - A review. Atmos. Environ. 67: 252-277.

Kumar, P., Morawska, L., Birmili, W., Paasonen, P., Hu, M., Kulmala, M., Harrison, R.M., Norford, L. and Britter, R. (2014). Ultrafine particles in cities. Environ. Int. 66: 1-10.

Kumar, P., Rivas, I. and Sachdeva, L. (2017). Exposure of in-pram babies to airborne particles during morning dropin and afternoon pick-up of school children. Environ. Pollut. 159: 66-82.

Lanki, T., de Hartog, J.J., Heinrich, J., Hoek, G., Janssen, N.A., Peters, A., Stölzel, M., Timonen, K.L., Vallius, M., Vanninen, E. and Pekkanen, J. (2006). Can we identify sources of fine particles responsible for exercise-induced ischemia on days with elevated air pollution? The ULTRA study. Environ. Health Perspect. 114: 655-660.

Leal, T.F., Fontenele, A.P., Pedrotti, J.J. and Fornaro, A. (2004). Composição iônica majoritária de águas de chuva no centro da cidade de São Paulo. Quim. Nova 27: 855861.

Lovell, M.A., Robertson, J.D., Teesdale, W.J., Campbell, J.L. and Markesbery, W.R. (1998). Copper, iron and zinc in Alzheimer's disease senile plaques. J. Neurol. Sci. 158: 47-52.

Mathers, C.D., Stevens, G.A., Boerma, T., White, R.A. and Tobias, M.I. (2015). Causes of international increases in older age life expectancy. Lancet 385: 540-548.

Miranda, R.M., Andrade, M.F., Fornaro, A., Astolfo, R., de Andre, P.A. and Saldiva, P. (2012). Urban air pollution: a representative survey of $\mathrm{PM}_{2.5}$ mass concentrations in six Brazilian cities. Air Qual. Atmos. Health 5: 63-77.

Misra, C., Singh, M., Shen, S., Sioutas, C. and Hall, P.M. (2002). Development and evaluation of a personal cascade impactor sampler (PCIS). J. Aerosol Sci. 33: 1027-1047.

Norris, G., Duvall, R., Brown, S. and Bai, S. (2014). EPA positive matrix factorization (PMF) 5.0 fundamentals \& user guide, Prepared for the US Environmental Protection Agency, Washington, DC, by the National Exposure Research Laboratory, Research Triangle Park, USA.

Ogulei, D., Hopke, P.K. and Wallace, L.A. (2006a). Analysis of indoor particle size distributions in an occupied townhouse using positive matrix factorization. Indoor Air 16: 204-215.

Ogulei, D., Hopke, P.K., Zhou, L., Pancras, J.P., Nair, N. and Ondov, J.M. (2006b). Source apportionment of Baltimore aerosol from combined size distribution and chemical composition data. Atmos. Environ. 40: 396-410.

Osman L.M., Douglas J.G., Garden C., Reglitz K., Lyon J., Gordon S. and Ayres J.G. (2007) Indoor air quality in homes of patients with chronic obstructive pulmonary disease. Am. J. Respir. Crit. Care Med. 176: 465-472.

Ozgen, S., Becagli, S., Bernardoni, V., Caserini, S., Caruso,
D., Corbella, L., Dell'Acqua, M. Fermo, P., Gonzalez, R., Lonati, G., Signorini, S., Tardivo, R., Tosi, E., Valli, G., Vecchi, R. and Marinovich, M. (2017). Analysis of the chemical composition of ultrafine particles from two domestic solid biomass fired room heaters under simulated real-world use. Atmos. Environ. 150: 87-97.

Paatero, P. and Tapper, U. (1994). Positive matrix factorization: A non-negative factor model with optimal utilization of error estimates of data values. Environmetrics 5: 111-126.

Peled, R. (2011). Air pollution exposure: Who is at high risk? Atmos. Environ. 45: 1781-1785.

Pohl, H.R., Roney, N. and Abadin, H.G. (2011). Metal ions affecting the neurological system. Met. Ions Life Sci. 8: 247-262.

Polissar, A.V., Hopke, P.K., Paatero, P., Malm, W.C. and Sisler, J.F. (1998). Atmospheric aerosol over Alaska: 2. Elemental composition and sources. J. Geophys. Res. 103: 19045-19057.

Polizzi, S., Pira, E., Ferrara, M., Bugiani, M., Papaleo, A., Albera, R. and Palmi, S. (2002). Neurotoxic effects of aluminium among foundry workers and Alzheimer's disease. Neurotoxicology 23: 761-774.

Power, M.C., Weisskopf, M.G., Alexeeff, S.E., Wright, R.O., Coull, B.A., Spiro, A. and Schwartz, J. (2013). Modification by hemochromatosis gene polymorphisms of the association between traffic-related air pollution and cognition in older men: A cohort study. Environ. Health 12: 16.

Raizenne, M., Neas, L.M., Damokosh, A.I., Dockery, D.W., Spengler, J.D., Koutrakis, P., Ware, J.H. and Speizer, F.E. (1996). Health effects of acid aerosols on North American children: pulmonary function. Environ. Health Perspect. 104: 506-514.

Rivas, I., Viana, M., Moreno, T., Pandolfi, M., Amato, F., Reche, C., Bouso, L., Àlvarez-Pedrerol, M., Alastuey, A., Sunyer, J. and Querol, X. (2014). Child exposure to indoor and outdoor air pollutants in schools in Barcelona, Spain. Environ. Int. 69: 200-212.

Rohr, A.C. and Wyzga, R.E. (2012). Attributing health effects to individual particulate matter constituents. Atmos. Environ. 62: 130-152.

Saffari, A., Daher, N., Shafer, M.M., Schauer, J.J. and Sioutas, C. (2013). Seasonal and spatial variation of trace elements and metals in quasi-ultrafine $\left(\mathrm{PM}_{0.25}\right)$ particles in the Los Angeles metropolitan area and characterization of their sources. Environ. Pollut. 181: 14-23.

Sánchez-Ccoyllo, O.R., Ynoue, R.Y., Martins, L.D., Astolfo, R., Miranda, R.M., Freitas, E.D., Borges, A.S, Fornaro, A, Freitas H. and Andrade, M.F. (2009). Vehicular particulate matter emissions in road tunnels in São Paulo, Brazil. Environ. Monit. Assess. 149: 241-249.

Segalin, B., Gonçalves, F.L.T. and Fornaro, A. (2016). Black Carbon em material particulado nas residências de idosos na Região Metropolitana de São Paulo, Brasil. Rev. Bras. Meteorol. 31: 311-318.

Segalin, B., Kumar, P., Micadei, K., Fornaro, A. and Gonçalves, F.L.T. (2017). Size-segregated particulate matter in indoor residences of elderly in the Metropolitan Area of São Paulo, Brazil. Atmos. Environ. 148: 139-151. 
Sheikh, J.I., Yesavage, J.A., Brooks, J.O., Friedman, L., Gratzinger, P., Hill, R.D., Zadeik, A. and Crook, T. (1991). Proposed factor structure of the Geriatric Depression Scale. Int. Psychogeriatr. 3: 23-28.

Shi, G., Xu, J., Peng, X., Xiao, Z., Chen, K., Tian, Y., Guan, X., Feng, Y., Yu, H., Nenes, A. and Russell, A.G. (2017). $\mathrm{pH}$ of aerosols in a polluted atmosphere: Source contributions to highly acidic aerosol. Environ. Sci. Technol. 51: 4289-4296.

Shimodaira, H. (2002). An approximately unbiased test of phylogenetic tree selection. Syst. Biol. 51: 492-508.

Shimodaira, H. (2004). Approximately unbiased tests of regions using multistep-multiscale bootstrap resampling. Ann. Stat. 32: 2616-2641.

Sioutas, C. (2004). Development of New Generation Personal Monitors for Fine Particulate Matter (PM) and its Metal Content. Mickey Leland National Urban Air Toxics Research Center. p. 29.

Steenland, K., Sanderson, W. and Calvert, G.M. (2001). Kidney disease and arthritis in a cohort study of workers exposed to silica. Epidemiology 12: 405-412.

Suzuki, R., and Shimodaira, H. (2009). pvclust: Hierarchical clustering with p-values via multiscale bootstrap resampling. $\mathrm{R}$ package version 1.2.1.

Tan, H., Tian, H., Verbeeck, J., Monico, L., Janssens, K. and Van Tendeloo, G. (2013). Nanoscale investigation of the degradation mechanism of a historical chrome yellow paint by quantitative electron energy loss spectroscopy mapping of chromium species. Angew. Chem. Int. Ed. 52: 11360-11363.

Torkmahalleh, M.A., Goldasteh, I., Zhao, Y., Udochu, N.M., Rossner, A., Hopke, P.K. and Ferro, A.R. (2012). $\mathrm{PM}_{2.5}$ and ultrafine particles emitted during heating of commercial cooking oils. Indoor Air 22: 483-491.

Trezza, B.M., Apolinario, D., de Oliveira, R.S., Busse, A.L., Gonçalves, F.L.T., Saldiva, P.H.N. and Jacob-Filho, W. (2015). Environmental heat exposure and cognitive performance in older adults: A controlled trial. Age 37: 43.

United Nations (2015) World Population Prospects: The 2015 Revision, Key Findings and Advance Tables. United Nations, Department of Economic and Social Affairs, Population Division. ESA/P/WP.241. p. 66. https://esa.un.org/unpd/wpp/Publications/Files/Key_Find ings_WPP_2015.pdf, Last Access: 10 May 2016.

Viana, M., Rivas, I., Querol, X., Alastuey, A., Sunyer, J., Álvarez-Pedrerol, M., Buoso, L. and Sioutas, C. (2014). Indoor/outdoor relationships and mass closure of quasiultrafine, accumulation and coarse particles in Barcelona schools. Atmos. Chem. Phys. 14: 4459-4472.
Vieira-Filho, M., Pedrotti, J.J. and Fornaro, A. (2016a). Water-soluble ions species of size-resolved aerosols: Implications for the atmospheric acidity in São Paulo megacity, Brazil. Atmos. Res. 181: 281-287.

Vieira-Filho, M.S., Ito, D.T., Pedrotti, J.J., Coelho, L.H. and Fornaro, A. (2016b). Gas-phase ammonia and watersoluble ions in particulate matter analysis in an urban vehicular tunnel. Environ. Sci. Pollut. Res. 23: 1987619886.

Vu, T.V., Ondracek, J., Zdímal, V., Schwarz, J., DelgadoSaborit, J.M. and Harrison, R.M. (2017). Physical properties and lung deposition of particles emitted from five major indoor sources. Air Qual. Atmos. Health 101: $1-14$.

Wallace, L. (2006). Indoor sources of ultrafine and accumulation mode particles: Size distributions, sizeresolved concentrations, and source strengths. Aerosol Sci. Technol. 40: 348-360.

Wallace, L.A., Ott, W.R. and Weschler, C.J. (2015). Ultrafine particles from electric appliances and cooking pans: Experiments suggesting desorption/nucleation of sorbed organics as the primary source. Indoor Air 25: 536-546.

Weber, R.J., Guo, H., Russel, A.G. and Nenes, A. (2016). High aerosol acidity despite declining atmospheric sulfate concentrations over the past 15 years. Nat. Geosci. 9: 282-286.

Weuve, J., Puett, R.C., Schwartz, J., Yanosky, J.D., Laden, F. and Grodstein, F. (2012). Exposure to particulate air pollution and cognitive decline in older women. Arch. Int. Med. 172: 219-227.

Wyzga, R.E. and Folinsbee, L.J. (1995). Health effects of acid aerosol. Water Air Soil Pollut.85: 177-188.

Ynoue, R.Y. and Andrade, M.F. (2004). Size-resolved mass balance of aerosol particles over the São Paulo metropolitan area of Brazil. Aerosol Sci. Technol. 38: 5262.

Zatta, P., Lucchini, R., van Rensburg, S.J. and Taylor, A. (2003). The role of metals in neurodegenerative processes: Aluminum, manganese, and zinc. Brain Res. Bull. 62: 1528.

Zatta, P. and Frank, A. (2007). Copper deficiency and neurological disorders in man and animals. Brain Res. Rev. 54: 19-33.

Received for review, September 17, 2019 Revised, February 6, 2020 Accepted, March 31, 2020 